\title{
Polyhydroxyalkanoates production by a bacte- rium isolated from mangrove soil samples collected from Quang Ninh province
}

\author{
Vi khuẩn sinh tổng hơp polyhydroxyalkanoates phân lập tì đất rù̀ng ngập mặn \\ tỉnh Quảng Ninh
}

Research article

Doan, Thuoc Van*; Nguyen, Binh Thi

Department of Microbiology and Biotechnology, Faculty of Biology, Hanoi National University of Education, 136 Xuan Thuy, Cau Giay, Hanoi, Vietnam

\begin{abstract}
A PHA producing bacterium (strain QN271) was selected from mangrove soil samples collected from Quang Ninh province by using the Nile red dying technique. PHA accumulation in the selected bacterium strain was confirmed by transmission electron microscope. With the exception of maltose or sucrose, the bacterium strain was found to be able to synthesize PHA from various carbon sources (glucose, xylose, fructose, glycerol, and glucose plus propionate). The strain accumulated poly(3-hydroxybutyrate) from glucose, fructose, xylose, and glycerol whereas poly(3-hydroxybutyrate-co-3-hydroxyvalarate) was produced when a combination of glucose and propionate was included in the culture medium. Fructose was found to be most suitable substrate for PHA synthesis by strain QN271. PHA content of 63.3\% and CDW of $6 \mathrm{~g} / \mathrm{L}$ were obtained after $32 \mathrm{hrs}$ of cultivation in fructose medium.
\end{abstract}

Chủng vi khuẩn có khả năng sinh tổng hợp PHA đã được phân lập tù đất rùng ngập mặn tỉnh Quảng Ninh nhò kỹ thuật nhuộm với Nile red. Anh quan sát duới kính hiển vi điện tủ dẫn truyền chứng tỏ rằng chủng vi khuẩn này có khả năng tích lũy lương lón PHA trong tế bào. Chủng vi khuẩn tuyển chọn có khả năng sinh tổng hợp PHA tù̀ nhiều nguồn các bon khác nhau nhu glucose, xylose, fructose, glucerol, glucose và propionate nhung không có khả năng tổng hợp PHA tùv maltose hoạc saccharose. Chủng vi khuẩn tuyển chọn tổng hợp poly (3-hydroxybutyrate) tù các nguồn các-bon nhu glucose, xylose, fructose, hay glycerol, trong khi đó poly (3-hydroxybutyrateco-3-hydroxyvalarate) sẽ được tổng hợp khi phối hợp sư dụng hai nguồn các-bon (glucose và propionate). Fructose là nguồn các-bon tốt nhất cho chủng QN271 sinh tổng hợp PHA, khi nuôi cấy trong môi truò̀ng có fructose chủng vi khuẩn này có thể tạo ra luợng sinh khối là $6 \mathrm{~g} / \mathrm{L}$ trong đó có chứa $63.3 \%$ PHA sau 32 giò.

Keywords: biopolymer, mangrove, poly(3-hydroxybutyrate), polyhydroxyalkanoate

\section{Introduction}

Mankind has become highly dependent on fossil resources for their need of energy, chemicals and materials. However, the fossil resources will sooner or later come to an end and also that they are found only in some regions of the world. That has led to a global interest in finding alternative sources that are renewable and easily accessible. The other problem that motivates a shift from fossil resources is the negative environmental impact of the processes and products in terms of greenhouse gas emissions, global warming and climate change. Fossil energy and plastics are among the most environmentally damaging products used in enormous amounts (Braunegg et al., 1998). The current global consumption of plastics is more than 250 million tonnes with annual increase in consumption of approximately $5 \%$. In order to overcome the problem of pollution caused by non-degradable plastics, there is considerable interest in the development of biodegradable polymers such as polyhydroxyalkanoate (PHA), polylactic acid (PLA) (Lee, 1996; Salehizadeh and Van Loosdrecht, 2004). 
Polyhydroxyalkanoates (PHAs) are polyester of hydroxyalkanoates, accumulated intracellularly as carbon and energy storage materials in numerous microorganisms, usually when growing under the limitation of a nutrient and in the presence of excess carbon (Anderson and Dawes, 1990; Valappil et al., 2007). After extraction from the cells, PHAs possess the common features of nontoxic, biocompatible, biodegradable and recyclable thermoplastics. The main applications of PHAs include replacing petrochemical polymers currently in use for packaging and coating, as well as disposable plastic items. PHAs are also widely employed as bone plates, osteosynthetic materials, surgical sutures, vascular grafts and heart valves (Philip et al., 2007).

Mangrove forests are specialized ecosystems situated at the inter-phase between land and sea of the tropical and subtropical areas. Mangrove forests occupy a total estimated area of $152,000 \mathrm{~km}^{2}$ and distributed in 123 countries and territories (Spalding et al., 2010). Microbes play an important role in governing the biogeochemical cycles of any ecosystem. Many different microorganisms including bacteria, fungi, protozoa and algae have been found in mangrove ecosystems. Among these microbes, the bacterial population is many-fold greater than the other. Because of its diversity, bacterial activity is responsible for most of the mineral cycle and the carbon flux in the mangrove ecosystems, and act as a carbon sink (Holguin et al., 2001).

The present study reports the isolation of a PHA accumulating bacterium from soil samples collected from mangrove forests located at Yen Hung district, Quang Ninh province. The ability to produce PHA from different carbon sources by the isolate strain was also investigated.

\section{Materials and methods}

\subsection{Isolation of bacterial strains}

Soil samples from mangrove forests located at Yen Hung district, Quang Ninh province were collected and serially dilluted with sterile sea water, and then $100 \mu \mathrm{L}$ of the dilution were spread on solid HM medium (Quillaguamán et al. 2004), containing ( $\mathrm{g} / \mathrm{L}): \mathrm{NaCl}, 30 ; \mathrm{MgSO}_{4} .7 \mathrm{H}_{2} \mathrm{O}$, $0.25 ; \mathrm{CaCl}_{2}, 0.09 ; \mathrm{KCl}, 0.5 ; \mathrm{NaBr}, 0.06$; peptone, 5; yeast extract, 10; glucose, 1; and granulated agar, 20; and $\mathrm{pH}$ was adjusted to 7 using $2 \mathrm{~N} \mathrm{NaOH}$ solution. The plates were incubated at $35^{\circ} \mathrm{C}$ for $30 \mathrm{~h}$. Several hundreds of colonies were isolated by plating them again on fresh agar medium.

\subsection{Detection of PHA in bacteria}

Bacterial isolates were grown on a modified solid HM medium (HM-1) containing (g/L): $\mathrm{NaCl}, 30 ; \mathrm{MgSO}_{4}$. $7 \mathrm{H}_{2} \mathrm{O}, 0.25 ; \mathrm{CaCl}_{2}, 0.09 ; \mathrm{KCl}, 0.5 ; \mathrm{NaBr}, 0.06 ; \mathrm{KH}_{2} \mathrm{PO}_{4}$, 0.25 , yeast extract, 2; glucose, 20; granulated agar, 20; $\mathrm{pH}$ adjusted to 7 using $2 \mathrm{~N} \mathrm{NaOH}$, and Nile red (Sigma) (dissolved in dimethylsulfoxide) with final concentration of $0.5 \mu \mathrm{g}$ dye per $\mathrm{mL}$ of the medium. Petri dishes were incubated at $35^{\circ} \mathrm{C}$ for 2 days. The agar plates were then exposed to ultraviolet light $(312 \mathrm{~nm})$ to detect the presence of intracellular PHA granules in the bacteria. The colonies with fluorescent bright orange were chosen for further studies (Spiekermann et al., 1999).

\subsection{Transmission electron microscopy (TEM) observation}

PHA containing cells were fixed and observed under TEM following a protocol reported previously (Quillaguamán et al. 2006).

\subsection{Production of PHA by the isolated strain}

The selected bacterial strain was grown in $20 \mathrm{~mL}$ of $\mathrm{HM}$ medium in $100 \mathrm{~mL}$ flasks at $32^{\circ} \mathrm{C}$ with rotary shaking at $180 \mathrm{rpm}$ for $13 \mathrm{~h}$. Subsequently, $2.5 \mathrm{~mL}$ of each culture were inoculated in $250 \mathrm{~mL}$ Erlenmeyer flasks containing $50 \mathrm{~mL}$ of HM-1 medium with different carbon sources. The cultures were incubated at $32^{\circ} \mathrm{C}$ with rotary shaking at $180 \mathrm{rpm}$. Samples were withdrawn at $30 \mathrm{~h}$ of cultivation for cell dry weight (CDW) and PHA content analysis.

\subsection{Quantitative analysis}

CDW was determined by centrifuging $3 \mathrm{~mL}$ of the culture samples at $4000 \mathrm{rpm}$ for $10 \mathrm{~min}$ in a pre-weighed centrifuge tubes, the pellet was washed once with $3 \mathrm{~mL}$ distilled water, centrifuged and dried at $105^{\circ} \mathrm{C}$ until constant weight was obtained. The centrifuge tube was weighed again to calculate the CDW.

PHA content analysis was performed using a gaschromatographic method (Huijberts et al., 1994). Sample volume of $2 \mu \mathrm{L}$ was injected into the gas chromatography column (VARIAN, Factor Four Capillary Column, CP8907). The injection temperature was $250^{\circ} \mathrm{C}$, the detector temperature was $240^{\circ} \mathrm{C}$, and the column temperature was $60^{\circ} \mathrm{C}$ for the first 5 minutes and then increased at $3^{\circ} \mathrm{C} / \mathrm{min}$ to $120^{\circ} \mathrm{C}$. PHB and PHBV containing $12 \%$ valerate (Sigma) were used as a standard for calibration.

\section{Results and discussion}

\subsection{Isolation and detection of PHA producing bacteria from soil samples}

Several different bacteria were isolated from soil samples collected from mangrove forests located at Yen Hung district, Quang Ninh province. Three hundred randomly chosen colonies were collected and grown on agar HM medium. The isolate strains were then re-cultivated on agar HM-1 medium containing Nile red for 2 days and then exposed to UV light. The dye produced orange fluorescence on binding to PHA granules or other lipid storage compound in the cell (Figure 1). About fifty of fluorescent bacteria were observed, among them one bacterial strain that exhibited a very strong fluorescence was selected for further studies, named as QN271 (where QN means Quang Ninh). 


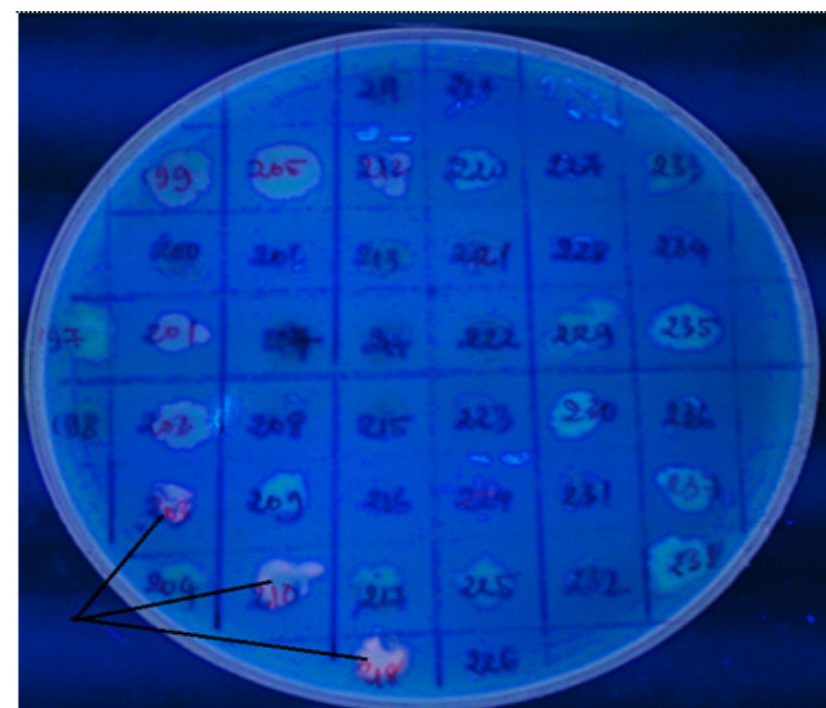

Figure 1. Fluorescent Nile red staining of strains from mangrove soil samples. The dye produces orange fluorescence on binding to polymer granules in the cell
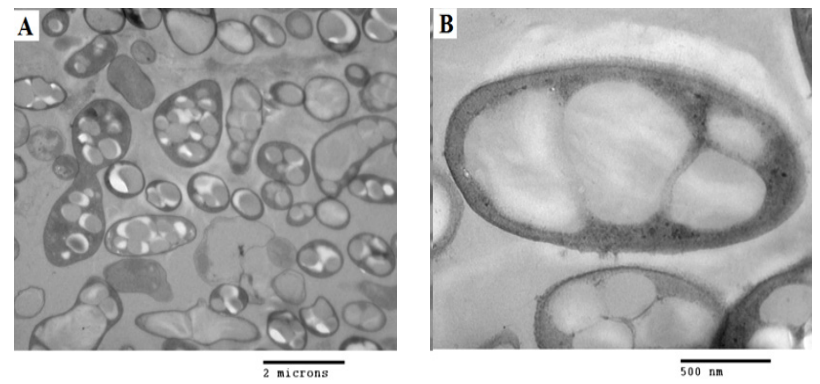

Figure 2. Transmission electron micrographs of strain QN271 grown on HM-1 medium with glucose for $48 \mathrm{~h}$
To confirm the formation of PHA granules in the selected bacterial strain, cells from the $48 \mathrm{~h}$ cultures grown on HM1 medium (without Nile red) were observed on a transmission electron microscope. Most of the cells of selected strain showed the presence of PHA granules in the cytoplasm (Figure 2A, 2B). As shown in the figure, PHA exists as gray granules, with about 1 to 10 granules per cell and with maximum diameter of $0.5 \mu \mathrm{m}$.

\subsection{PHA production from different carbon sources by the selected strain QN271}

One of the most important factors affecting PHA production is the carbon sources. In this concern, the effect of different carbon sources on PHA production by the selected strain QN271 was investigated. As showed in Table 1 PHA was accumulated by strain QN271 when glucose, xylose, fructose, glycerol, and glucose plus propionate were used as sole carbon source. However, the remaining two carbon sources (maltose and sucrose) were not induced the synthesis of PHA by strain QN271. Fructose was found to be most suitable for growth and PHA accumulation. The maximum PHA content of $60.5 \%$ and $\mathrm{CDW}$ of $5.5 \mathrm{~g} / \mathrm{L}$ were attained when fructose was used as carbon source. Gas chromatography analysis of the PHA indicated that 3-hydroxybutyrate (3HB) is the main component of the polymer, 3-hydroxyvalerate was only found in the polymer when glucose and propionate were supplied. Propionate has been used as a precursor for $3 \mathrm{HV}$ synthesis by many bacterial strains (Chen et al., 1991; Reddy et al., 2009). In this study the presence of propionate in the culture broth was also induced the synthesis of $3 \mathrm{HV}$ by the selected strain QN271.

Table 1. Effect of different carbon sources on cell growth and PHA accumulation by the selected strain QN271

\begin{tabular}{|c|c|c|c|c|c|c|}
\hline \multirow[t]{2}{*}{ Carbon source } & \multirow{2}{*}{$\begin{array}{l}\text { CDW } \\
(\mathrm{g} / \mathrm{L})\end{array}$} & \multirow{2}{*}{$\begin{array}{l}\text { PHA content } \\
(\% \text { CDW) }\end{array}$} & \multirow{2}{*}{$\begin{array}{l}\text { PHA conc. } \\
(\mathrm{g} / \mathrm{L})\end{array}$} & \multirow{2}{*}{$\begin{array}{l}\text { PHA produc- } \\
\text { tivity }(\mathrm{g} / \mathrm{L} / \mathrm{h})\end{array}$} & \multicolumn{2}{|c|}{ Monomer composition (mol\%) } \\
\hline & & & & & $3 \mathrm{HB}$ & $3 \mathrm{HV}$ \\
\hline Glucose & 5.0 & 47.6 & 2.39 & 0.08 & 100 & 0 \\
\hline Maltose & 3.4 & 0 & 0 & 0 & 0 & 0 \\
\hline Xylose & 4.3 & 28.9 & 1.25 & 0.04 & 100 & 0 \\
\hline Sucrose & 3.4 & 0 & 0 & 0 & 0 & 0 \\
\hline Fructose & 5.5 & 60.5 & 3.33 & 0.11 & 100 & 0 \\
\hline Glycerol & 4.6 & 36.5 & 1.67 & 0.06 & 100 & 0 \\
\hline Glucose + propionate & 4.7 & 31 & 1.46 & 0.05 & 95 & 5 \\
\hline
\end{tabular}

\subsection{PHA polymer production by the selected strain QN271 in fructose medium}

The effect of incubation time on cell growth and PHA accumulation by strain QN271 when grown in HM-1 medium containing fructose as carbon source was investigated. As showed in the Figure 3, strain QN271 grew rapidly and reached stationary phase within $32 \mathrm{~h}$. The CDW, PHA content, and PHA concentration increased until hour $32^{\text {th }}$ of cultivation and were $6 \mathrm{~g} / \mathrm{L}, 63.3 \%$, and $3.82 \mathrm{~g} / \mathrm{L}$, respectively (Figure 3 ). The PHA content of $63.3 \%$ and CDW of $6 \mathrm{~g} / \mathrm{L}$ reached in flask experiments by strain QN271 were lower than those reached by Azotobacter vinelandii $(74 \%$ and $10 \mathrm{~g} / \mathrm{L})$ (Page, 1992), Cupriavidus necator $(54 \%$ and $9.4 \mathrm{~g} / \mathrm{L})$ (Doi et al., 1988) and a recombinant $E$. coli strain $(80.8 \mathrm{wt} \%$ and $8.9 \mathrm{~g} / \mathrm{L})$ (Lee $e t$ al., 1994). These bacteria attained among the highest productions of PHA, and are recognized for their potential utilization at industrial scales. 


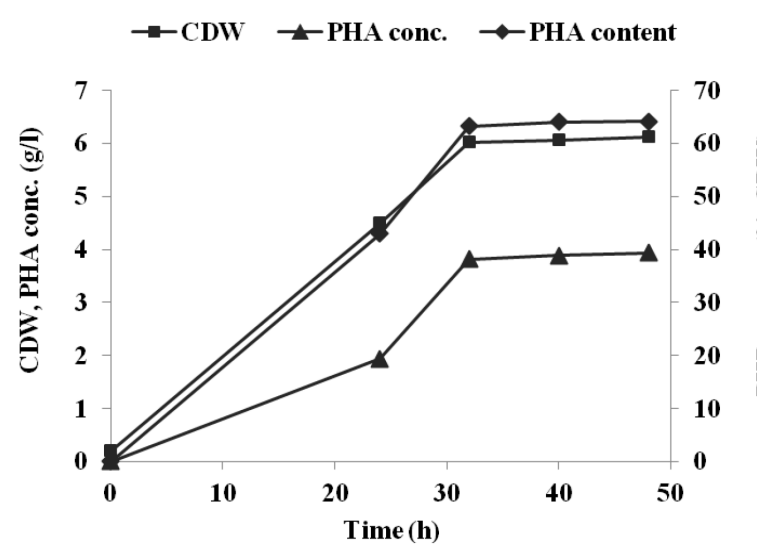

Figure 3. CDW, PHA content and PHA concentration of strain QN271 as a function of incubation time

\section{Conclusion}

A PHA producing bacterium strain QN271 was isolated from soil samples collected from Quang Ninh mangrove. The bacterium strain was able to accumulate high PHA (PHB or PHBV) from different carbon sources. Maximum PHA content of $63.3 \%$ and CDW of $6 \mathrm{~g} / \mathrm{L}$ were obtained by strain QN271, the results obtained here are comparable to that of the highest reported so far for other microorganisms. Further work on improving PHA production by strain QN271 is being investigated.

\section{Acknowledgements}

The authors are grateful to the National Foundation for Science and Technology Development (Grant no. 106.032010.64) and International Foundation for Science (Grant no. F/5021-1) for supporting this work.

\section{References}

[1] Anderson, A.J., Dawes, E.A. 1990. Occurrence, metabolism, metabolic role, and industrial uses of bacterial polyhydroxyalkanoates. Microbiol Rev 54: $450-472$

[2] Braunegg, G., Lefebvre, G., Genser, K.F., 1998. Polyhydroxyalkanoates, biopolyesters from renewable resources: physiological and engineering aspects. J Biotechnol 65: 127-161

[3] Chen, G.Q., Konig, K.H., Lafferty, R.W. 1991. Occurrence of poly-D (-)-3-hydroxyalkanoates in the genus Bacillus. FEMS Microbiol Lett 84:173-176

[4] Doi, Y., Tamaki, A., Kunioka, M., Soga. K. 1988. Production of copolyesters of 3-hydroxybutyrate and 3-hydroxyvalerate by Alcaligenes eutrophus from butyric and pentanoic acids. Appl Microbiol Biotechnol 28: 330-334

[5] Holguin, G., Vazquez, P., Bashan, Y. 2001. The role of sediment microorganisms in the productivity, conservation, and rehabilitation of mangrove ecosystems: an overview. Biol Fertil Soils 33:265278

[6] Huijberts, G.N.M., van der Wal, H., Wilkinson, C.,
Eggink, G. 1994. Gas-chromatographic analysis of poly(3-hydroxyalkanoates) in bacteria. Biotechnol Tech 8: 187-192

[7] Lee, S.Y., 1996. Plastic bacteria? Progress and prospects for polyhydroxyalkanoate production in bacteria. Trends Biotechnol 14: 431-438

[8] Lee, S.Y., Lee, K.M., Chang, H.N., Steinbüchel, A. 1994. Comparison of recombinant Escherichia coli strains for synthesis and accumulation of poly-(3hydroxybutyric acid) and morphological changes. Biotechnol Bioeng 44: 1337-1347

[9] Page, W.J., Sherburne, R., D’Elia, L., Graham, L.L. 1995. Poly(b-hydroxybutyrate) extrusion from pleomorphic cells of Azotobacter vinelandii UWD. Can J Microbiol 41(Suppl. 1): 22-31

[10] Philip, S., Keshavarz, T., Roy, I. 2007. Polyhydroxyalkanoates: biodegradable polymers with a range of applications. J Chem Technol Biotechnol 82: 233247

[11] Quillaguamán, J., Delgado, O., Mattiasson, B., Hatti-Kaul, R. 2006. Poly( $\square$ hydroxybutyrate) production by a moderate halophile, Halomonas boliviensis LC1. Enz Microb Technol 38: 148-154

[12] Quillaguamán, J., Hatti-Kaul, R., Mattiasson, B., Alvarez, M.T., Delgado, O. 2004. Halomonas boliviensis sp. nov., an alkalitolerant, moderate halophile bacterium isolated from soil around a Bolivian hypersaline lake. Int J Syst Evol Microbiol 54: 721725

[13] Reddy, S.V., Thirumala, M., Mahmood, S.K. 2009. Production of PHB and P(3HB-co-3HV) biopolymers by Bacillus megaterium strain OU303A isolated from municipal sewage sludge. World J Microbiol Biotechnol 25: 391-397

[14] Salehizadeh, H., Van Loosdrecht, M.C.M. 2004. Production of polyhydroxyalkanoates by mixed culture: recent trends and biotechnological importance. Biotechnol Adv 22: 261-279

[15] Spalding, M., Kainuma, M., Collins, L. eds. 2010. World atlas of mangroves Washington D.C.: Earthscan LCC.

[16] Spiekermann, P., Rehm, B.H., , Kalscheuer, R., Baumeister, D., Steinbüchel, A. 1999. A sensitive, viable-colony staining method using Nile red for direct screening of bacteria that accumulate polyhydroxyalkanoic acids and other lipid storage compounds. Arch Microbiol 171: 73-80

[17] Valappil, S.P., Boccaccini, A.R., Bucke, C., Roy, I. 2007. Polyhydroxyalkanoates in Gram-positive bacteria: insights from the genera Bacillus and Streptomyces. Antonie van Leeuwenhoek 91: 1-17 